University of Massachusetts Amherst ScholarWorks@UMass Amherst

2005

\title{
Worrying the line: Black women writers, lineage, and literary tradition.
}

S Tracy

Follow this and additional works at: https://scholarworks.umass.edu/afroam_faculty_pubs

\section{Recommended Citation}

Tracy, S, "Worrying the line: Black women writers, lineage, and literary tradition." (2005). STUDIES IN AMERICAN FICTION. 66. 10.1353 /saf.2005.0001

This Article is brought to you for free and open access by the Afro-American Studies at ScholarWorks@UMass Amherst. It has been accepted for inclusion in Afro-American Studies Faculty Publication Series by an authorized administrator of ScholarWorks@UMass Amherst. For more

information, please contact scholarworks@library.umass.edu. 


\section{REVIEWS}

Wall, Cheryl A. Worrying the Line: Black Women Writers, Lineage, and Literary Tradition. Chapel Hill: Univ. of North Carolina Press, 2005. xii +309 pp. Cloth: $\$ 49.95$. Paper: $\$ 19.95$.

Cheryl Wall's Worrying the Line is an important study of contemporary women writers that integrates notions of artistry and modality associated with African American vernacular music with the textual strategies of writers seeking to subvert, revise, and extend the American and African American literary traditions. For Wall, black women writers represent the multidimensionality of cultural identity by reconstructing family genealogies through the variety of available oral, visual, and written records of existence.

What Wall describes as the "blues trope" (7) for the book is the idea of "worrying the line," a technique whereby singers in the African American blues tradition, as described by Sherley Anne Williams, make use of "changes in stress and pitch, the addition of exclamatory phrases, changes in word order, repetition of phrases within the line itself, and the wordless blues cries that often punctuate the performance of the songs" to emphasize, clarify, or subvert meaning. Wall extends this trope to the techniques of the writers under discussion to subvert, revise, or extend notions of familial and literary lineage, which gives voice to previously unimagined or unheard race, class, sexual preference, and gender-informed stories. The trope, she acknowledges, is directly related to the "repetition with a difference" (16) that characterizes Henry Louis Gates's discussion of signifying in The Signifying Monkey. Wall sets these stories in the context of the American literary tradition as a whole, and the black male American literary tradition more specifically-since both form part of the literary tradition in which women write-but most specifically in the context of how the particulars of women's lives, including the lives of the blues singers who have been used as models of behavior by various writers, affect those traditions as well.

Wall's study provides discussions of works by Lucille Clifton, Gayl Jones, Audre Lorde, Paule Marshall, Toni Morrison, Gloria Naylor, and Alice Walker that are rigorous, discerning, and broad ranging. In her chapter "Reconstructing Lineage, Revising Tradition," Wall explores the differing trajectories of quest stories that emerge from the explorations of written and oral origins of black literature in Toni Morrison's Song of Solomon and Audre Lorde's Zami. Here Wall sees worrying the line as "a trope for reconfiguring lineages and for new ways of writing that configuration." W. E. B. DuBois' The Souls of Black Folk is posited as an important literary ancestor for Morrison (and African American writers in general), among other works like The Odyssey, The Old Testament, Invis- 
ible Man, Go Down, Moses, and One Hundred Years of Solitude. Similarly, the discussion of Lucille Clifton's Generations explores in a similarly discerning and insightful way the aesthetic, political, and spiritual affinities between Clifton and Walt Whitman as Clifton worries her African American genealogy out of Whitmanian epic through the juxtaposition of text and photographs. Of course, the influence of important female literary ancestors like Zora Neale Hurston are delineated as well, most fully in the outstanding chapter on Walker's The Color Purple and in conjunction with the work of Richard Wright in the excellent chapter on In Search of Our Mothers' Gardens. Wall is at her most concrete, specific, and effective in her discussions of Jones and Walker, employing blues history, subject matter, stylistics, and criticism to demonstrate how crucial the blues are to these works.

There are a few issues that might benefit from a bit more explanation and exploration. Although Wall identifies worrying the line as an element of the blues tradition, it clearly operates in other African American vernacular music as well. Wall discusses this subject in relation to Praisesong for the Widow, but that is chapter eight of a nine chapter book. An in-depth discussion of the subject early on would have informed the discussions of some of the other works as well-perhaps even sparked some more complete discussions. Wall makes it clear that the blues has provided the impetus for a number of the writers under discussion, but a discussion of the relationship of techniques among African American musical genres, including those sometimes (problematically) separately categorized as sacred and secular, may have provided a worried genre line that could have added dimension to her discussions.

Providing specific examples of how worrying the line works in particular examples from the vernacular music tradition would have made this characteristic of the tradition more concrete for readers, and perhaps could have led to a correlation between an instance in a recording and in one of the texts under discussion. It would have been helpful for Wall to make more crucial connections between the blues tradition and her genealogies here. After all, blues singers have been compared to African griots and griottes, one of whose main functions has been to provide genealogies for the community. Although these discussions are not absolutely necessary, they would have added more specific connections between the blues and literary traditions that would have emphasized the African American vernacular connection more concretely throughout. That, in turn, would have delineated more fully how the "worrying the line" technique differs - if it does - from any other attempt to demonstrate how the tradition is altered by contemporary readings and individual poetic talent, as in T.S. Eliot's Anglo-Modernist readings of literary ancestors such as the metaphysical poets in relation to his work. Regardless, Wall has provided readers with an excellent study of how a variety of contemporary women writers have examined, altered, and extended the literary and cultural 
context for the work they do, and she has done it in an intelligent, clearly written, and entertaining fashion.

Steven Tracy

University of Massachusetts, Amherst

Jackson, Cassandra. Barriers Between Us: Interracial Sex in Nineteenth-Century American Literature. Bloomington and Indianapolis: Indiana Univ. Press. 2004. 146 pp. Cloth: \$49.95. Paper: \$19.95.

The current celebration of cultural hybridity runs the risk of fetishizing hybridity and naturalizing the imagined connections between cultural hybridity and mixed-race bodies. In order to gain a fuller understanding of this insidious fetishism of the "mix," we need to historicize the fetishism tied to interracialness even as we uncover the subversive layers of images of interracialness in nineteenth century American literature. Cassandra Jackson's Barriers Between Us: Interracial Sex in Nineteenth Century American Literature complicates the longstanding tendency to assess the progressiveness of nineteenth century images of interracialness. She refuses to simply see "almost white" characters as a courting of white audiences; she wonders about many different audiences and many different depictions of these "almost white" characters. She insists that the focus on interracialness becomes immensely productive as writers find new ways of thinking about boundaries of the nation itself. This very focus on the productive nature of this interracial "play" leads to a fresh analysis that defamiliarizes the tragic mulatto script.

Why did this paradigm gain the ability to define images of the interracial in nineteenth century American literature? Jackson's study reveals that we need less critique of the melodrama and a greater consideration of the complex issues of desire and contradictions underneath this melodrama. Her exploration of the different uses of mixed-race characters gains real momentum when she argues that Chesnutt and Hopkins use mixed-race characters to think specifically about the intraracial negotiations in African American communities as opposed to the more typical investment in black and white relations. In Iola Leroy and Mandy Oxendine, she argues that interracialness becomes a productive space for the representation of a certain type of black activism. This argument leads to questions reminiscent of Toni Morrison's inquiry in Playing in the Dark: Whiteness and the Literary Imagination. As we think more about the role of interracialness in African American literature, Morrison's title transposes into "Playing in the Light: Interracialness and the Black Literary Imagination." Even as Jackson analyzes the work of both white and black authors, she provides a very helpful foundation for work addressing the ways in which mixed- 